\title{
(9) $\frac{10}{\mathrm{a}}$ \\ magining Septembers \\ PRINCIPLES AND DESIGN ELEMENTS \\ FOR AMBITIOUS SCHOOLS \\ DURING COVID-19
}

\section{Justin Reich, MIT Teaching Systems Lab \\ Jal Mehta, Harvard Graduate School of Education}

\section{tsl.mit.edu/COVID19}

Images by:

Haley McDevitt | haleymcdevitt.com

Kelvy Bird | www.kelvybird.com

Sita Magnuson | dpict.info

Suggested Citation: Reich, J. \& Mehta J. (2020) Imagining September:

Principles and Design Elements for Ambitious Schools during Covid-19.

Retrieved from https:/ledarxiv.org/gqa2w

UIf 2 TEACHING SYSTEMS LAB

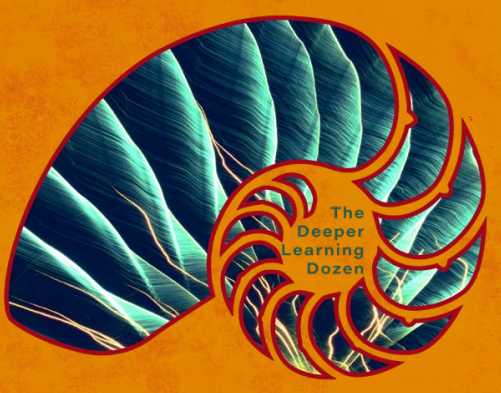




\section{Executive Summary}

In May 2020, we facilitated four online design charrettes with a variety of school stakeholders-students, teachers, principals, district leaders, parents, consultants, state officials, and others-to develop a design process for fall 2020 school planning. We describe these charrettes and provide resources for facilitating similar events in an additional report Imagining September: Online Design Charrettes for Fall 2020 Planning with Students and Stakeholders.

This report shares insights from those design meetings. First we identified seven themes that emerged from our design charrettes:

1. Relationships are the Foundation of Schooling

2. Liberatory Approaches to Equity

3. Amplifying Student Agency

4. Marie Kondo-ing School Priorities

5. Building Time will be Gold

6. Nurturing Home and Community Learning

7. Iterative Organizational Learning

For each of these principles, we developed a small set of "storyboards," short vignettes of future classroom life in the 2020-2021 school year as told from students and faculty. Through these stories, educators can begin to imagine what hybrid schooling might look like next year.

These storyboards range widely in grain size from "tentpole" ideas that could organize a school's entire reopening plan to smaller programmatic pieces that could fit into many different types of responses. It would be nearly impossible to include all of these design elements in a single reopening plan, and some of them contradict one another. However, reviewing these storyboards can help school communities begin their own process of storytelling about schooling next year. 


\section{MAGINNG SEPTEMBER}

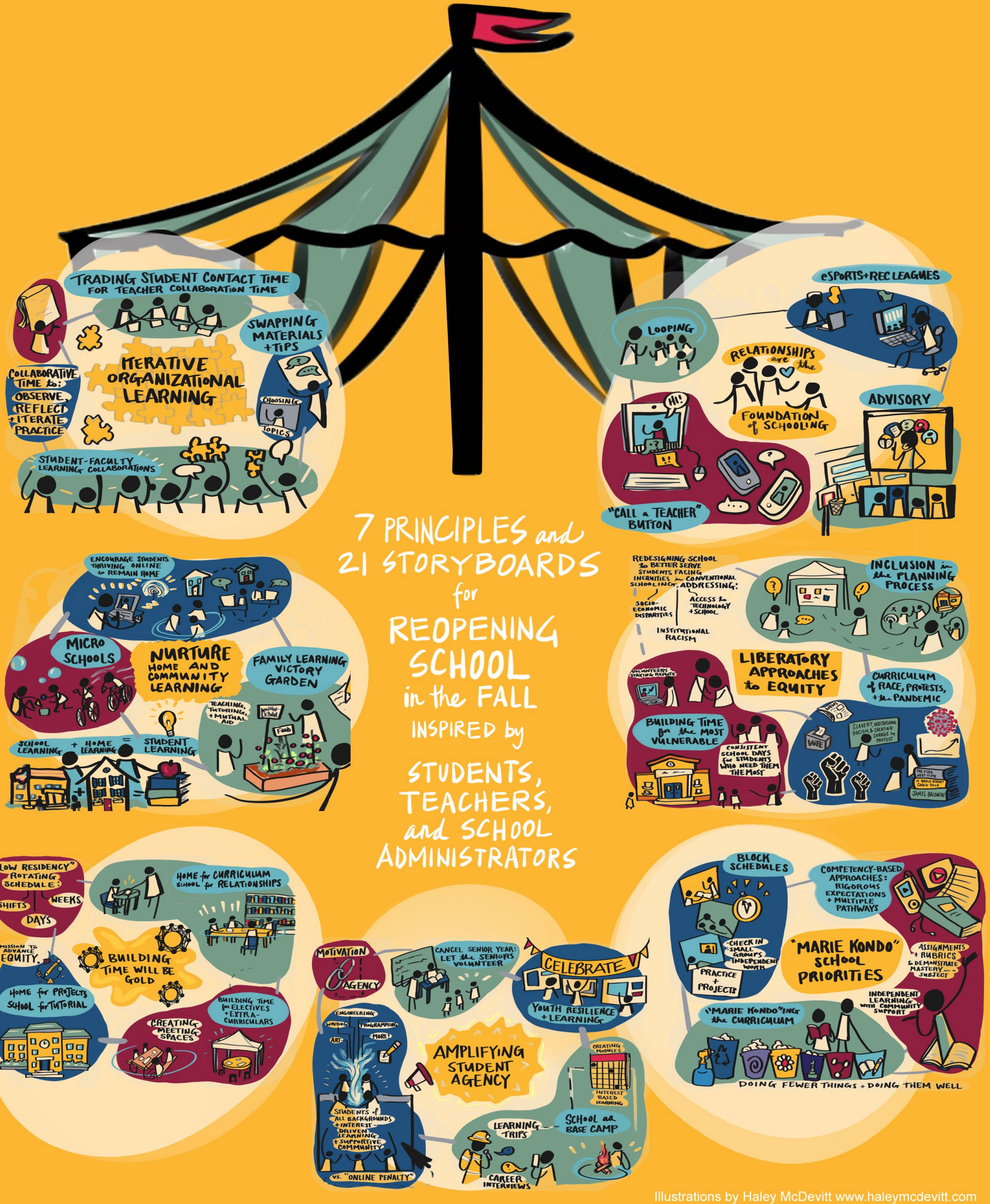




\section{Introduction}

With the summer upon us, we have a brief moment to reflect, plan, and think about what we would like schools to look like next year. With that in mind, we convened four charrettes this past spring, composed of students, teachers, principals, parents, district administrators, state officials, and other key stakeholders. In this document, we provide two results of this effort:

- Key principles for thinking about redesign for next year, as identified by these charrettes

- Scenarios that illustrate what these principles might look like in practice

In an accompanying document, we also offer:

- A process that schools and districts can use to run their own charrettes.

Our effort was driven by three observations:

The first is that many of the discussions about school reopening are largely technical in nature. There is a lot of discussion about how to space the students, which days students will go to school, how to transport students to school, and so forth. These are important discussions and we do not want to minimize the importance of keeping students safe. But if they are not grounded in values or principles about what we want for students and what produces good educational experiences, then they are not likely to work or achieve their best results.

The second observation is that, almost by necessity, what we have done thus far has been more reactive than forward-looking. Schools were asked to change with little notice and did a heroic job of trying to move existing content online. But the literature on online learning shows that it is its own space, with its own affordances and limitations, which deserves its own design. Presumably the fall will be a hybrid or blended space, with some time physically in school and some at home, and thus we will need new designs that meet this new challenge.

The third is that there are many resources available which provide a comprehensive checklist of things that districts would need to do before fall (See the Appendix in Imagining September: Online Design Charrettes for Fall 2020 Planning with Students and Stakeholders. Our suggestion is that you use this process in conjunction with one of those resources. This process will help you to identify your values, see what sorts of educational experiences are most valued in your community, and brainstorm a set of possibilities for how to best achieve those ends. After you've defined your educational vision, and some "tentpole ideas" for how to achieve that vision, you can use one of those resources to work on the details of how best to realize that vision safely.

\section{Three Overarching Design Guidelines}

We also think there are some overarching design guidelines that schools and districts should consider in this environment. School should develop:

1. One set of shared values;

2. A few simple common structures;

3. Many local experiments, with lots of mechanisms for reflecting, learning, and improving those experiments as you go 
Why those three? Essentially COVID-19 represents what complexity theorists would describe as a highly complex and uncertain situation. In those environments, the right organizational form is one that is modular and adaptive; in other words you don't know exactly what is going to work, nor is it clear that what works in one context will work in another. You want to let people closest to the ground innovate and then make sensible adaptations as they see what is working. You keep what works, and seek to spread it, and you abandon what doesn't work. Fortunately schools are already what organizational theorists call "loosely coupled systems" (where individual actors show great discretion in interpreting and following top-down policies), and thus this kind of approach is working with the grain of the organization of schools.

At the same time, you need some common direction, which is where the shared values come in. As $\underline{\text { Peter }}$ Senge has shown, you can privilege local experimentation if people are generally rowing in the same direction; in the absence of that common direction, local innovation will produce incoherence. Research as far back as the effective schools literature in the 1970s, through research on Catholic schools in the 80s, to research on some of the most innovative schools today, consistently shows that having a common mission, which is not just written on a website but is internalized and acted on by its members, is key to school success.

While you want to privilege local adaptation, this spring has shown that having some basic common structures is important for creating the shared infrastructure on top of which experimentation can happen. Picking a common technology platform and developing a common interface across grades and subjects, for example, makes it possible for students and parents to focus on the content of the work rather than navigating the websites. Creating some commonalities can also encourage learning -if, for example, a district or state decides that every school will go to a one day on, one day off schedule, it is more possible to learn across schools than it would be if every school developed its own schedule. At the same time, people will resent what they perceive as constraints imposed from above, whereas they tend to "own what they create," so any common requirements should be few in number, and developed through a process that involves considerable input from those affected by it.

We should also say that decades of learning about schools suggests that the success of any process or structure is heavily dependent upon the culture in which it is embedded. Peter Drucker famously said that "culture eats strategy for breakfast" and that seems to be particularly true for schools. Building cultures where teachers, students, and parents feel included and listened to, where they are co-developers of the directions that are taken, is itself perhaps the most important factor that differentiates sustainably successful schools from those that are not. Later in this document, we offer a process that embodies these commitments, but this process will only help if it is taken up within an ongoing spirit of collaboration and codevelopment.

Relatedly, complex and uncertain environments require ongoing adaptation and learning. This is iterative. This means that while schools can run charrettes over the summer, and build modular structures that allow for local adaptation, the design as a whole will only work if there is ongoing learning and reflection, in real time, over the course of the year. In turn, this will require building some enabling structures - particularly time and space for learning - but it also requires leadership at the level of districts, schools, departments, and grade level teams. This is more like tending a garden than programming a machine - it requires ongoing attention and support for it to work. Thus, while we are offering a design that we hope can get schools off to the right start and organize themselves into the right structures, for those designs and structures to come to fruition will require considerable leadership and careful attention from those involved in the enterprise. 


\section{Seven Principles for Schooling in a Time of COVID-19}

1. Relationships are the Foundation of Schooling: Over and over again, our participants told us what should be obvious but often gets lost in our industrial era structures: relationships are the key to everything. If schools don't find a way to build strong relationships next year, they are not likely to succeed in their educational enterprise.

2. Liberatory Approaches to Equity: Any decisions that we make need to be woven through with explicit considerations of equity. Inequity is structurally baked into the system, and thus we need to directly address it if it is going to enable all students to succeed. A liberatory approach to equity means that we need to think of equity not simply in terms of promoting academic achievement for students of color and poverty-impacted youth but in finding ways to re-envision learning experiences so that they are relevant, purposeful, and meaningful for all learners. It also means that we need to examine our systems, structures, processes, pedagogies, and culture to see how they can be made more equitable. Equity also requires inclusivity in design and decision-making, so that it represents the full diversity of learners.

3. Amplifying Student Agency: As students have spent more time outside the confines of physical school, they have had to become more responsible for their learning and for their lives. Schools have responded by trying to replicate the structures of schools from afar. But we suspect that schools will be more successful if they lean into students' growing sense of agency, and find ways to build on and amplify it.

4. Marie Kondo-ing School Priorities: Students have missed some school, and they will not have as much physical school time next year. Given that, successful schools will need ways to prioritize. Our participants suggest that "Marie Kondo-ing" these priorities -- retaining what creates joy, and discarding what is non-essential -- is how schools might think through this question.

5. Building Time Will Be Gold: Time in the building is now a scarce resource, in a way that it never has been before, and, given the fluctuations of COVID-19, it is something that can be taken away at any time. Students are also starved for human contact and being able to do things physically with their peers and their teachers. Given that, schools should think very carefully about how best to use the in-person time, as opposed to what can be done at home.

6. Nurturing Home and Community Learning: The coronavirus fundamentally shifts the relationship between home and school. Schools found this out the hard way this spring, as they enlisted parents and caregivers to be monitors of school learning. With students at home likely half the time, schools need to build stronger partnerships with families and communities, and create environments that will enable students to work successfully away from school.

7. Iterative Organizational Learning: As we have stated above, given the uncertainties that will continue to exist about this fundamentally new situation, teachers and schools will need to engage in ongoing reflection, learning and adaptation. Building the time, space, structures, flexibility, and most of all, the mindsets for this kind of continuous learning and improvement is likely to be critical for success

To some degree, many of these notions are ideas that would be good under any circumstances. But we, and the participants in our charrettes, suggested that they would be especially important under the circumstances we face next year. 


\section{How to Use What Follows}

The seven principles described above were consistently voiced by the stakeholders in our charrettes. In the sections below, we describe each principle briefly, and then we have developed a small set of "storyboards," short, fictional vignettes of future classroom life in the 2020-2021 school year as told from the perspective of students and faculty. Through these invented stories about the future, educators can begin to imagine what hybrid schooling might look like next year.

These storyboards range widely in grain size from "tentpole" ideas that could organize a school's entire reopening plan to smaller programmatic pieces that could fit into many different types of responses. It would be nearly impossible to include all of these design elements in a single reopening plan, and some of them contradict one another. However, reviewing these storyboards can help school communities begin their own process of storytelling about schooling next year.

We would suggest that you run your own charrettes (see Imagining September: Online Design Charrettes for Fall 2020 Planning with Students and Stakeholders), which will allow you to develop your own sense of what is important in your community. Assuming that you might land on some similar themes, what is presented below are some specific ideas about how you might actualize those themes in practice. They are intended as pieces that can support the design of a coherent whole -- you can take some but not others, but it will work better if you develop a unified vision of what you are trying to do and a plan for how the pieces can fit together. 


\section{Relationships are the Foundation of Schooling}

When schools closed in March of 2020, educators faced many different obstacles, but they had one distinctive advantage: they had already invested seven months in building relationships between teachers and students and among classmates. As our colleague Neema Avashia said to her middle school students during a design charrette, "You guys know that when I call or text to harass you about your school work, you already know that I love you. If I have new students and call them to bug them about their work, it's not going to be the same."

Relationships are the foundation of schooling: the trust forged between teachers and students inspires learners to do their

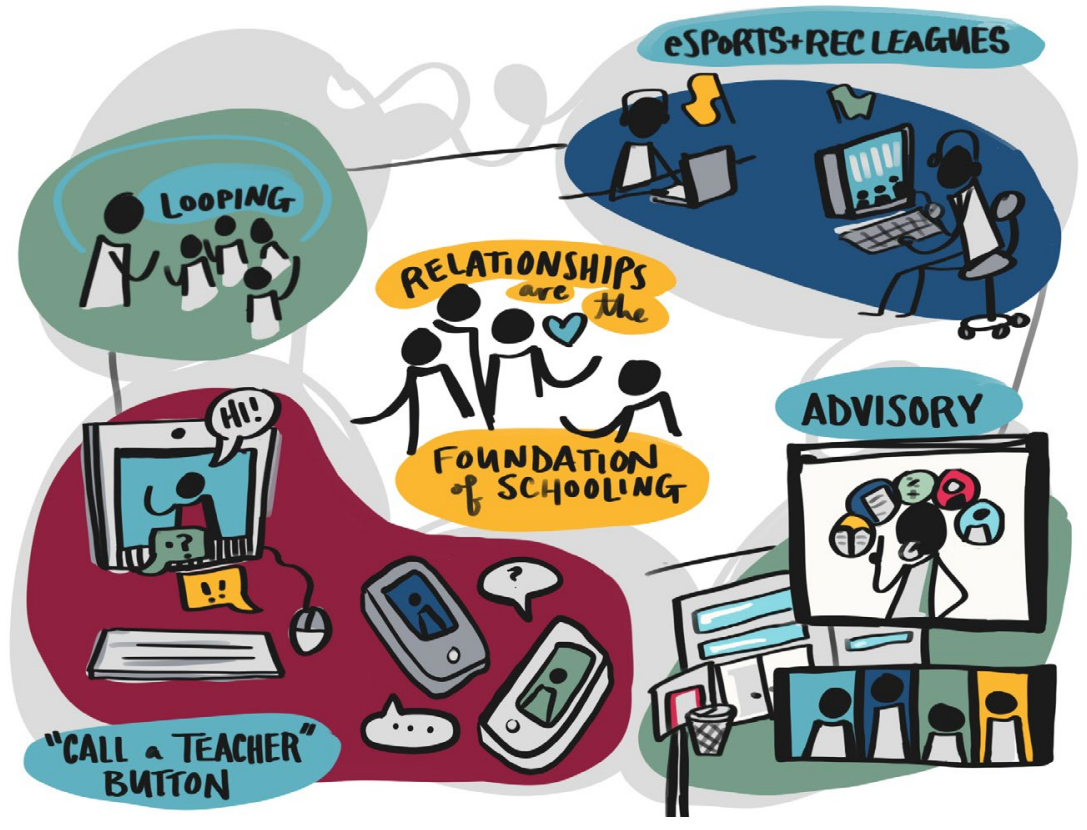
work, enables teachers to offer candid feedback and criticism, and helps teachers learn to find the keys that unlock student potential and learning. Schools have a wide variety of mechanisms, formal and informal, for developing relationships, and many of the proposed safety regulations for next year interfere with those mechanisms. It is going to be more challenging to build community if students come in on alternating days, have to spend their whole school day in one classroom at one desk, and cannot freely move about campus to connect with teachers, peers, clubs, extra help, and other social structures.

At schools that use hybrid or full remote schedules next year, educators and students will need to team up to develop new kinds of strategies and structures for forging the relationships that enabled meaningful learning. Below, we offer four such structures, that range from small innovations to major rethinking of how we organize schooling.

\section{"Call a Teacher" Button}

It's funny what you miss from regular school. When we're in class or in study hall, I can just raise a hand and a teacher will come and help me with my work, or answer a question. Last spring when we were doing school from home, when I had a question I could email a teacher, but sometimes they were busy and when they got back to me I had forgotten about the problem or got busy with something else.

This year, our school had us install a "Call a Teacher" bookmark in our browser. It goes to a webpage with text chat and with a link to a video conference room. Pretty much all day long, there is at least one teacher

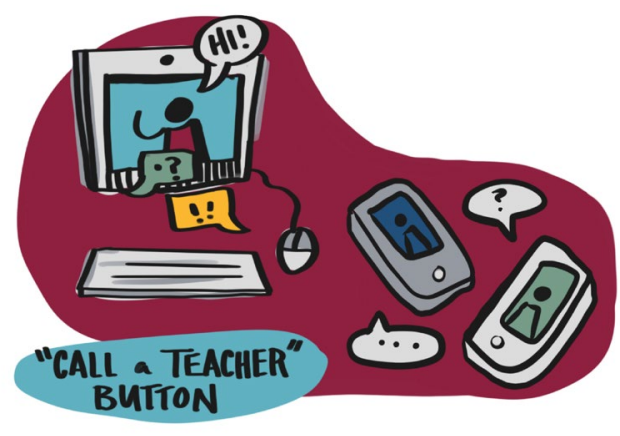
hanging out waiting to help students in both places. A lot of times, it's the librarian. If you are stuck on a homework problem, they'll find you a video or something. If an assignment isn't clear, they'll read it with you and try to tell you what it means, and if they can't figure it out, they start texting the teacher or whoever made the assignment. They get pretty busy late at night, so there are a bunch of extra teachers on then to help them, and they use breakout rooms and things. I still text my own teachers first, but when they are busy, I use Call a Teacher. 
I've used it a few times, and it's pretty nice. They always ask me a bunch of other stuff too... Did I get enough to eat today? Am I getting enough sleep? Those kinds of things. It's pretty bad that we can only go into school a couple of days a week, because things are really boring at home, but I appreciate that teachers are trying to look out for us, even the ones that we don't know very well.

\section{Advisories}

It's 1 p.m., and we just finished our Monday advisory Zoom. Last year, we did advisory first thing in the morning, but lots of students sleep in during their "off weeks," so for this year the school switched advisory to noon. We're rotating weeks through the middle school campus since the second wave hit; we spend one week on campus and then two weeks learning remotely from home. This is my second home week.

My advisor this year is Mr. McCallum, who is the PE teacher, but he's kind of my "everything" teacher this year. I've got nine other kids in the advisory, and Mr. Burns is like our school coach. He makes sure

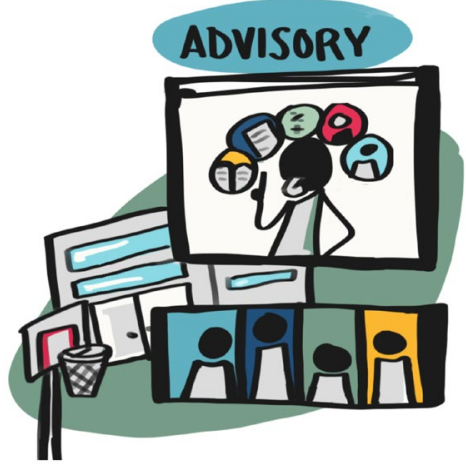
that we each understand our grid of online lessons and assignments for the week. On a home week like this, he texts us a couple of times every day to see what we're working on, and we can always call him if we have questions. We meet a couple of times by zoom one-on-one throughout the week, too. Sometimes he teaches me things that I don't get, and sometimes he helps me connect with a math or English teacher in another advisory.

During the school weeks, rather than rotating among six teachers, we just have one math/science teacher in the morning and one history/humanities teacher in the afternoon. While the teachers don't always know the content in as much detail as they would if it were their subject, we don't feel as rushed because we have some longer blocks to explore things. It also allows us to see some of the connections between the subjects; Mr. West is really into Vietnam, and so we've looked at the history, literature, and even watched some movies about it.

School is still crazy with the second wave and everything, and it's still harder than a regular year, but it's much easier than last spring. Last spring my Mom and I had a really hard time figuring out what I was supposed to do when schools closed because I got different emails every week from teachers, and all kinds of different assignments and lessons. This year, Mr. Burns kind of walks me through everything and makes sure that I can figure out stuff that I don't get. He also hangs out with us... we play Pictionary or Jackbox on Thursday nights at $9 \mathrm{pm}$, which is cool of him to hang out with us.

\section{Further Reading:}

Matt Pearsall. The Challenge of Advisory and Why it's Worth the Effort. Association for Middle Level Education: https://www.amle.org/BrowsebyTopic/WhatsNew/WNDet/Tabld/270/ArtMID/888/ArticlelD/864/The-Challengeof-Advisory-and-Why-its-Worth-the-Effort.aspx

\section{Looping}

A student's view: I got Ms. Case again! She was my fourth grade teacher, and all of the fourth grade teachers became fifth grade teachers this year so we could have the same teacher. I like all of the fifth grade teachers, but since we only come into school every third week, it is much easier to come back to the same class and the same teacher. We have a routine from last year, and she knows what we studied last year and what we missed because of coronavirus, so that makes this year easier.Some of my friends didn't really like their teacher, and I feel bad for them, but it's pretty good for me.

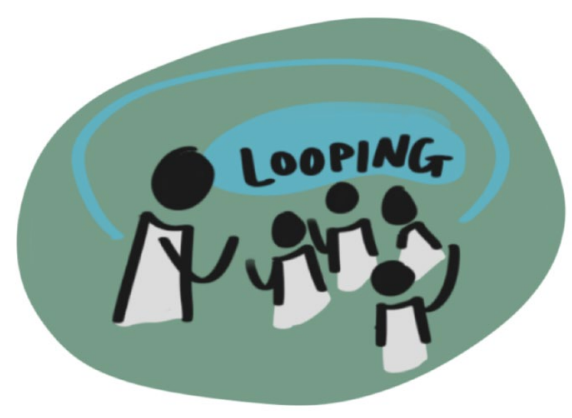


A principal's view: We met as a faculty over the summer and decided that it was really important for the kids to have continuity. Having their teacher from last year allows the student and faculty to maintain relationships, and it allows the faculty to know what students missed as they move into next year. We had to choose between two options. We could have everyone loop, in which case the fifth grade teachers would become kindergarten teachers. Or we could do a partial loop in which we paired the grades (K-1, 2-3, 4-5) and have teachers simply swap spots. In this scenario, the kindergarten teachers would loop to first grade, and the first grade teachers would go back to kindergarten. This has the advantage that no one has to teach a very different grade, but it also meant that only half the kids looped -- the first graders would go to second, where they would get a new teacher. We discussed it, and decided to go for looping for everyone. Two of the fifth grader teachers were willing to move back to kindergarten, and one moved to music, where we had an opening. It seems like it has worked really well -- while not every match is perfect, on the whole, building on the relationships we had over the first $2 / 3$ of last year has really helped us.

\section{Further Reading:}

Mark Rogers. Why students need looping now more than ever. Education Dive:

https://www.educationdive.com/news/why-students-need-looping-now-more-than-ever/576032/

Gail Conway. How Looping Works. Hechinger Report:

https://hechingerreport.org/opinion-how-looping-works/

\section{eSports and Rec Leagues}

It's Thursday night, which means it's time for Valorant Rec League! I really miss playing soccer and basketball, and I miss my coach and team, but this has been a pretty fun replacement.

Valorant is a new free-to-play five on five capture the flag type shooting game. Ms. Breeches, the librarian, organized a league for us. We all get on Discord at 8pm, and we have to have a parent come to the microphone and tell Ms. Breeches that we finished our homework. For about 15 minutes we watch a clip of some pro player or pro team, or

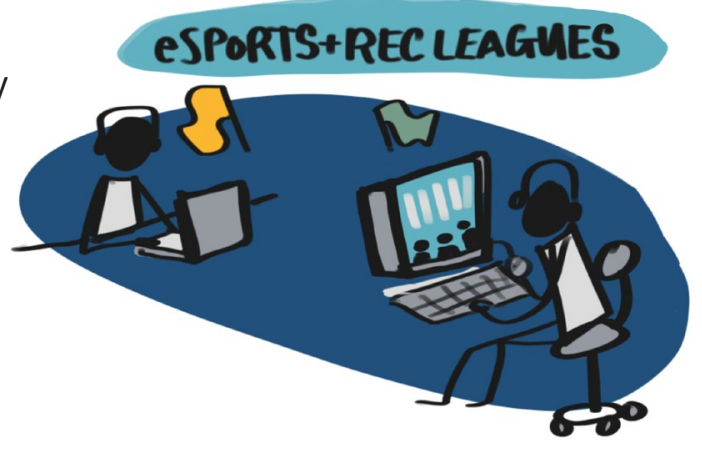
watch a short strategy video, and then we talk about it in Discord for a little bit, but then we just play until later in the evening.

Ms. Breeches uses a Google Doc to organize 5 person teams... sometimes we play against each other and sometimes we just play against other people. For the first half of the fall, we're just playing around randomly with different people and getting better, but she says she's going to organize a league tournament in the fall. We're also going to do some scrimmages with other schools in town.

Ms. Breeches puts herself on the teams and a few other teachers from school come and play with us sometimes. They are really bad, but it's still fun to hang out with them and show them how to play. My mom is pretty strict about COVID stuff, so I'm still really not allowed to just go and hang out with a bunch of friends, so I'm glad that I can go online and play games with my school friends.

\section{Further Reading:}

Lindsey Cesari. The Benefits of Esports in the School Library-and How To Start a Team. School Library Journal. https://www.slj.com/?detailStory=benefits-esports-school-library-how-to-start-team

Kara Yorio. Esports Leagues Continue To Play Despite School Closures. School Library Journal.

https://www.sli.com/?detailStory=esports-leagues-continue-to-play-despite-school-closures-coronavirus-covid19 


\section{Liberatory Approaches to Equity}

This pandemic has struck in predictably stratified ways, both in terms of racially and socio-economically disparate health outcomes, and in terms of who has had access to technology and schooling. The deaths of George Floyd, Breonna Taylor, and others have also highlighted ongoing institutional racism and inequity in our country. As we organize for the fall, we need to think about ways to attack these inequities on all levels, including in how we plan, and how we facilitate school in the fall. The batch processing and sorting functions of schools, from tracking to exam schools, have been one major mechanism for reproducing inequalities; redesign creates an opportunity to think

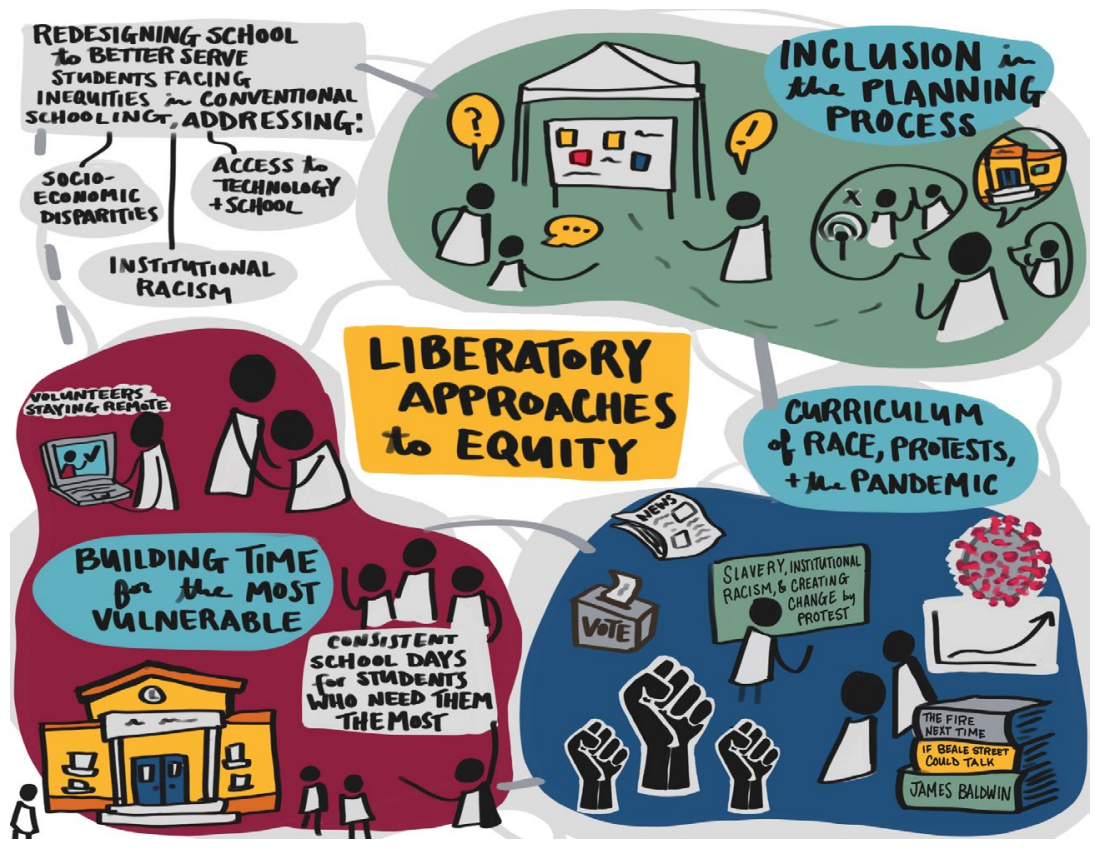
carefully about the needs and assets of different students and how a new approach can better serve all students, but particularly those that were least well-served by conventional schooling.

\section{Inclusion in the Planning Process}

In early July, I got a text from my friend saying that Mrs. Nicholson was looking for me. Last spring was tough--my parents are essential workers, and our internet doesn't work very well, so I spent most of the spring watching my brothers and didn't connect much with school. My teachers sent me a barrage of emails and the school sent some form letters, but no one really seemed to mind that I was gone.

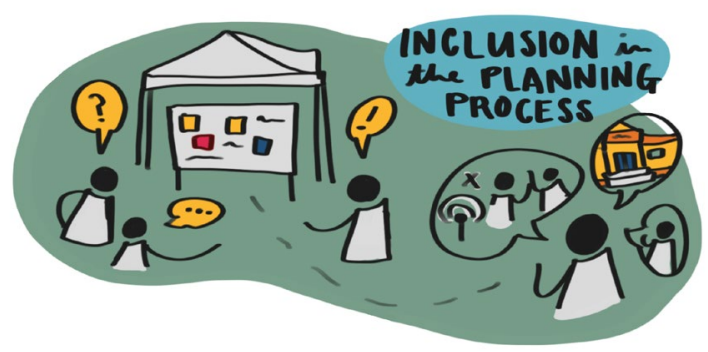

But when I heard that Mrs. Nicholson was looking for me, I knew I needed to hit her back. She wanted to invite me to this outdoor planning process that they were doing for next year. I'm not on the student council, I'm not a joiner -- usually when the school involves students, it's the same high track kids every year. But this was different; when I showed up for the summer design meetings, there were kids from every part of the school -- including lots of kids I hadn't seen in years because everything is so heavily tracked.

They asked us what our lives were like in the spring, and what we thought would be good for this year. I told them about our crappy internet and watching my brothers, and they said that they were impressed that I could take care of two little kids all day. We developed a plan for this year where kids like me are going to form a little pod with other families in my neighborhood, so there will be someone to watch my brothers when I need to go to school. We also decided that kids who had worse internet or no internet would go to physical school more, and those who had stronger connections or liked working from home would stay home more.

I'm excited about the fall; I helped develop this plan -- I'm looking forward to seeing if it works! 


\section{Curriculum of Race, Protests, and the Pandemic}

When I finally got back to school after six months out, I was excited that we were going to make current events a big part of the curriculum. So much had happened since we had real school -- first I was sheltering at home, then I went to some protests for George Floyd, and now the presidential election is coming up.

We started with a focus on the Black Lives Matter movement. We talked about the history of slavery and institutional racism, and the role of protest in creating social change. Then we also did some learning about the differential effects of the pandemic, and the ways that it has hit Black

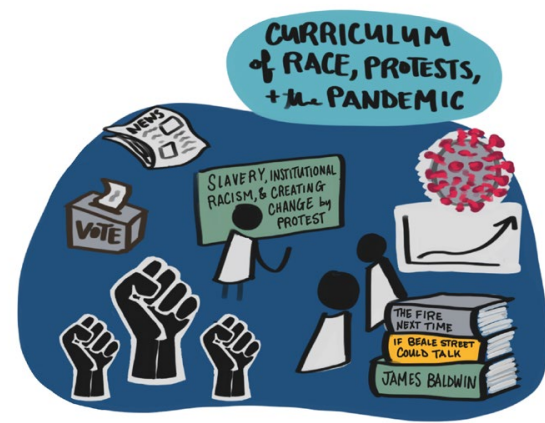
and Brown communities much harder than White ones. It was also cool because of the way it brought together the disciplines -- we learned about COVID and exponential growth in math, we read James Baldwin in English, and we learned about how all of this had developed in history.

It concluded with allowing us to take some action steps. We were given the challenge of trying to figure out how best to use our money and time to support a cause that we believed in. We had a debate about whether we should support voting rights, criminal justice reform, or educational reform. We interviewed some local changemakers as part of this process. At the end, we each had to develop a campaign in support of the cause that we believed in, and get others to come along with our campaign. It wasn't always easy, but I learned a lot, and I have a much better sense of the world I'm living in. I'm Black, and it was also nice that for once we weren't just the props in someone else's narrative, but my voice got to be the center of the story.

\section{Further Reading:}

Teaching Tolerance: Race and Ethnicity:

https://www.tolerance.org/topics/race-ethnicity

\section{Building Time for the Most Vulnerable}

My school decided that there we didn't all need to come to school all the time. They sent home a letter asking which kids had actually liked it at home last spring, and wanted to continue, and I know some of my friends took them up on it. They come to school about once or twice a week.

Meanwhile, other kids come every day. These include some kids who are homeless, as well as the kids who are in special ed, or need some pullout classes. Everyone whose parents are essential workers also comes school daily. And I go every day because my Dad is a teacher, and the district decided that, for transportation reasons, since the teachers were already coming to school, their kids also could come to school all the time.

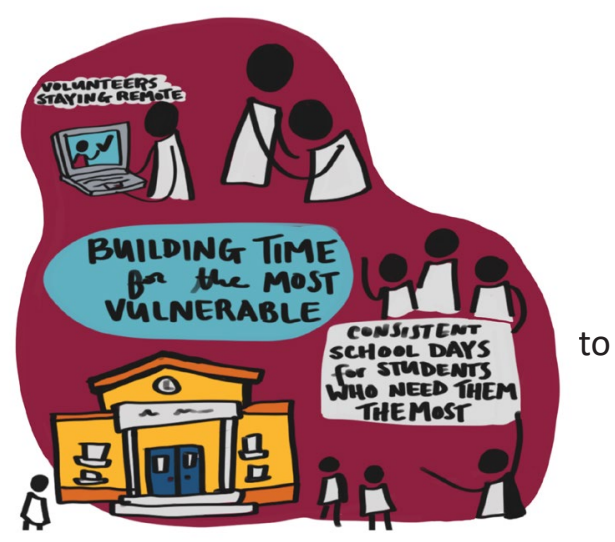

There were a few kids, including my friend, Chris, who wanted to come to school all the time, but there weren't quite enough spots. Ms. Schff was Chris' teacher last year, so she tried to talk to him. She explained to him that some kids have a hard time learning at home, and we need to have the schools be for the people who need them the most. Ms. Schiff said that during the pandemic, a lot of people had to be heroes who weren't expecting to be heroes, like grocery store workers and delivery people and stuff, and that he needed to be a hero so that the kids who really can't learn at home can come to school. Chris is still kind of mad about it, but I think he understands.

\section{Further Reading:}

Kevin Godden. Re-opening schools in British Columbia: A tale in three acts (so far!). The Learning Partnership. https://www.thelearningpartnership.ca/about/news-updates/blog/re-opening-schools-in-british-columbia-a-tale-in 


\section{Amplifying Student Agency}

The research around online schooling and online learning hinges around motivation.

Over the last decade, a body of evidence has emerged that in large-scale implementations of online learning, average students do less well than in comparable face-to-face settings. In for-profit colleges, in virtual high-schools, and in community colleges, students in online settings typically have lower GPAs and higher failure rates than students in face-to-face settings. This "online penalty" tends not to affect the most high achieving students;students who will do fine anywhere do fine online. But the online penalty is often more severe for our least well served students: students with low prior achievement, ethnic and racial minorities, and students experiencing poverty.

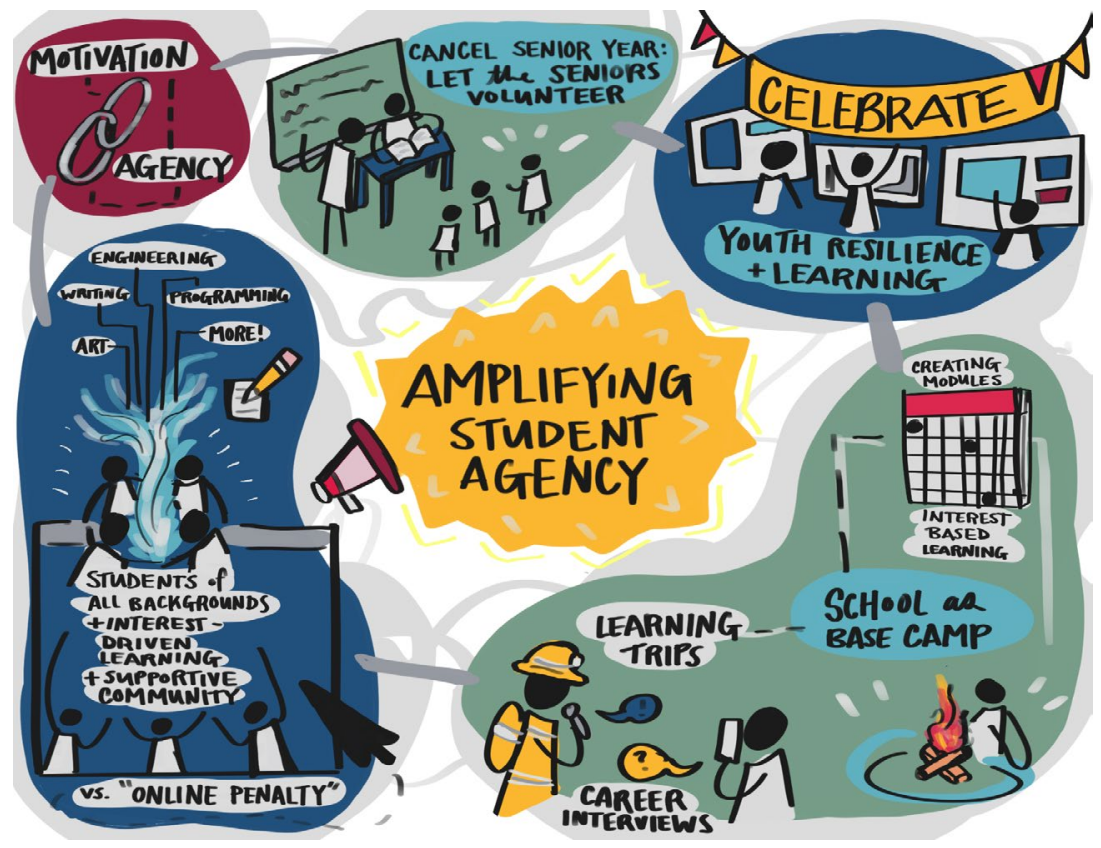

That said, there is also evidence that when students from all backgrounds engage in interest-driven learning online with a community of supportive peers and mentors, they can produce remarkable works of art, programming, engineering, writing, and more. When motivation and access are high, adolescents and young adults show great proficiency in learning online; unfortunately, student motivation to pursue typically assigned topics in school is not always high.

Motivation and agency are closely linked. Students often (though not universally) have greater motivation to explore topics when they have more control over what and how they study. For schools expecting to continue to rely extensively on online learning in the year ahead, educators may want to consider how greater student choice and autonomy can support the kinds of motivation that seem essential for successful online schooling.

\section{Celebrate Youth Resilience and Learning}

In normal years, we make a point to end the year with student performance of learning; when every student puts together a portfolio, shares a capstone project, and explains why they are ready to step up to the next grade. This year, when we could finally come back together in person, we wanted to start the year with a celebration of student learning.

Everything that I read this spring and summer about the pandemic was about learning loss, and about students falling behind in their subjects. One of my biggest fears for this fall is that all the students would return,

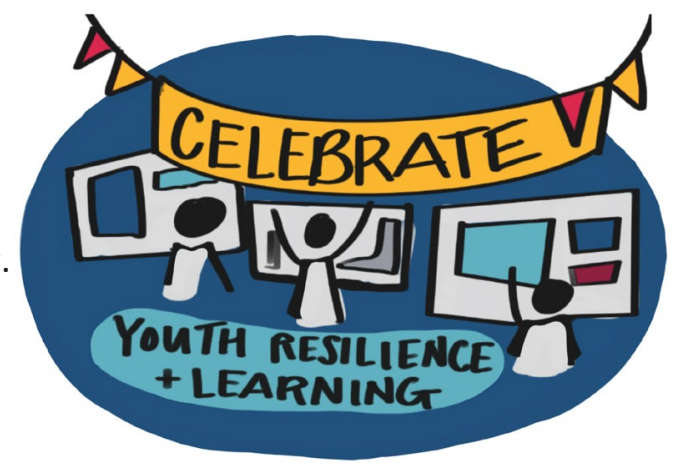
and we'd point at them--especially those living in homes with poor internet connections--and say to those kids, "Well, now you are really behind!"

There is no doubt that our students missed some important topics this past spring, but I saw so many of my students engaged in incredible learning experiences. My students learned how to organize themselves at home, how to use technology in new ways, how to participate in online learning, and how to help rebuild my classroom--and now our school-- in an unprecedented pandemic. Some of my students got new jobs, some learned how to be a teacher or tutor for a younger sibling, some of them learned how to organize protests, make their voice heard, and make 
change. They didn't learn everything that I hoped I'd be able to teach them this spring, but they did learn so many other amazing things. As a school, we wanted to celebrate their resilience and honor all of the learning that they have done.

So we started the year with a Celebration of Resilience, which was a mini-sprint where they developed a small portfolio and presentation showcasing the learning--academic and otherwise--they were most proud of over the last six months. As a teacher, those strengths and assets will be an important foundation as we examine how to address the few, important things that students did miss from last spring.

\section{School as Base Camp}

School this year is totally different. At the beginning of the year, our principal, Ms. Taggert, said that since schools couldn't open normally this year, we had to rethink everything. We couldn't do the old kind of school with social distancing, so for this year, we're trying a really new kind of school. Not everybody likes it, but I think most kids like it, or at least most kids like it more than grids we used last spring. I like it.

Ms. Taggert said that this year school is our base camp. We're coming to school to do different kinds of learning trips. Some of the trips we do with our class, some we do with our friends, and some we do on our own.

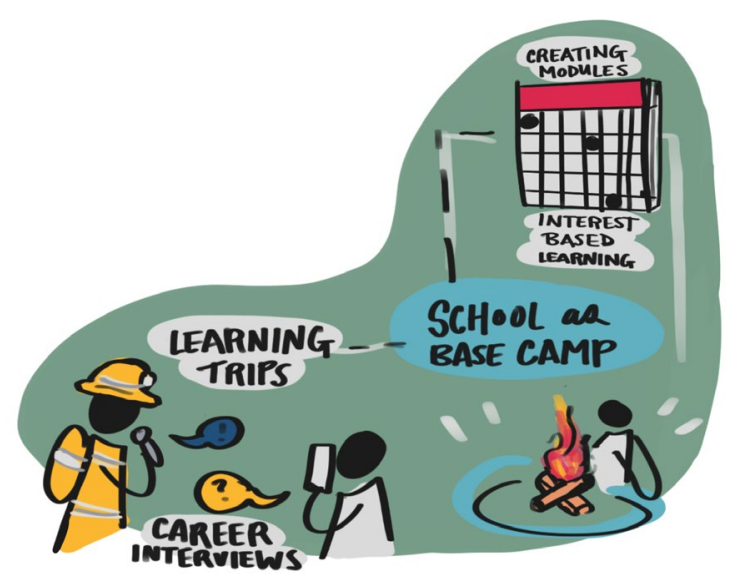

We spent the first two weeks of the year all doing a project on careers. We used this workbook from Roadtrip Nation to think about the things that we like and don't like, the things that we want to study and learn more about, and jobs and careers that we might be interested in. We all did a video interview with someone that we admire or did a job that we were interested in; I want to be a firefighter like my dad so I interviewed the fire chief. But kids in my class interviewed all kinds of people: doctors, nurses, barbers, the hardware store owner, teachers, all kinds of jobs. On our school days, our homeroom teachers helped us call people, schedule interviews, and write up interview questions. Then on one of our home days, we either went to the business to interview the person from 6 feet away and filmed it with our phones, or we interviewed them on video. For the last couple of days, we got into groups with people with similar jobs, like the firefighters, police, soldiers, and city hall workers all presented together, and we watched each other's videos and discussed what we learned.

After that, we got to choose a bunch of different modules that we'll do this year. All of the English teachers made up four modules each, and they run two every other month. So my favorite English teacher, Ms. Darling, had Reading about Science and Writing to Persuade. I'm going to do both, because she said that to be a firefighter, you have to understand stuff about water pressure and how buildings burn down and stuff like that. But if I'm going to be chief, then I'll have to write things that inspire all of the firefighters and make them want to do a good job, so I'm going to do that too. When you sign up for a module, you get a whole month's worth of stuff to do at the beginning of the month, and you have to do a project proposal in the middle of the month and a project presentation at the end. There are some things that everyone in the module will read all together, and then a bunch of research and other stuff that we do on our own.

Every month, we also get to make up our own module and project, so I'm doing one on fire science. Mr. Kent agreed to be my advisor for the project. It's hard, because I have to do a lot of it on my own, but the librarian helped me find some good videos and websites, and I'm starting to learn a lot. My dad has some books and things, but they are pretty hard to understand. But, I'm excited, because fires are really cool and if you learn a lot about them, you can figure out how to attack them and put them out. 
My homeroom teacher is Ms. Zabat. When we go into school, we mostly work on our own, but we all get to spend about a half an hour with the homeroom teacher. Ms. Zabat spends a few minutes online looking at what work I've done and what I haven't and comments from the module teachers, then she asks me how I'm doing, and what I need help with. I'm lucky that I come into school on Mondays, because she helps me make a plan for the week.

When we have a vaccine and everything is back to normal, I hope we can still do some of the school like this. I like having some of my classes just be about stuff that I'm interested in.

\section{Cancel Senior Year- Let the Seniors Volunteer}

I'm so tired. Today is my fourth week helping Ms. Crusher with her first graders, and I am exhausted! Teaching is so hard but I love it.

I never expected to spend my senior year in a first grade classroom, but here I am. This summer, the district announced that anyone who ended their Junior Year in good standing could bypass all of their senior year requirements, do 1,000 hours of volunteer work, and then graduate. I've been looking forward to senior year for years, but varsity soccer is canceled, remote learning classes are not that great, and we're not going to have homecoming or prom or any of the other great parts of senior year. When I learned that I could spend my whole year with my favorite teacher ever, Ms.

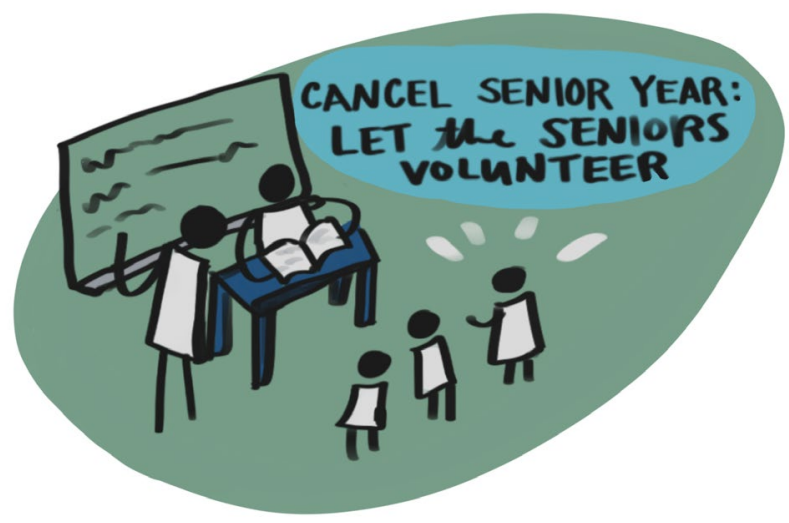
Crusher, I jumped at it.

This year, the town took an old school back from the senior center and turned it back into classrooms again, so we have two classrooms for Ms. Crushers 24 students. Ten come into a room with me, ten go with Ms. Crusher, and four have to rotate being at home. We trade back and forth; sometimes Ms. Crusher will team the same lesson to both classes, and I help supervise independent work in the other room, and sometimes she can show me how to teach or do something. I can do all the read alouds and I'm learning about choral counting and other things, but mostly I just help students with their handwashing, bathroom trips, and independent reading and things.

I meet once a week with my senior advisor and we all talk about our internships and what we're learning. Everyone in my advisory is teaching in schools, so we talk about teaching tips, and how to help the kids with all the new hygiene rules, and what kinds of colleges we should go to if we want to be teachers as a career. I'm also taking some online classes in the afternoons after the kids go home.

About half the seniors decide to volunteer. Some are teaching, some of the techy kids are helping in the IT department, and some are working for the town doing contact tracing or other kinds of things. A few pretty much just got jobs in local stores or with their parents. But the good thing is that a bunch of the teachers who usually teach senior classes can now help teach freshman or sophomores so more kids can come into school, and all the classrooms that seniors would have used can now be shared with other classes. I'm still pretty sad that we have such a weird senior year, but at least we get to try some things that no class has ever been able to do before, and I love spending the year with Ms. Crusher. 


\section{"Marie Kondo-ing" School Priorities}

Schools are being asked to take on a range of new responsibilities--addressing pandemic health management, conducting deep sanitization and cleaning, running dual-track low-residency/remote learning programs-with budgets that will likely face significant cuts. For all their incredible growth and resilience during the pandemic, students are returning to school with mixed experiences with remote learning, new gaps in their understanding of core curriculum content, and the wounds of recession, family job loss, police violence, and pandemic-related deaths. Schools are being asked to do much more for students with greater needs and disparities with far fewer resources, after an exhausting spring.

To the challenges, educators need to bring

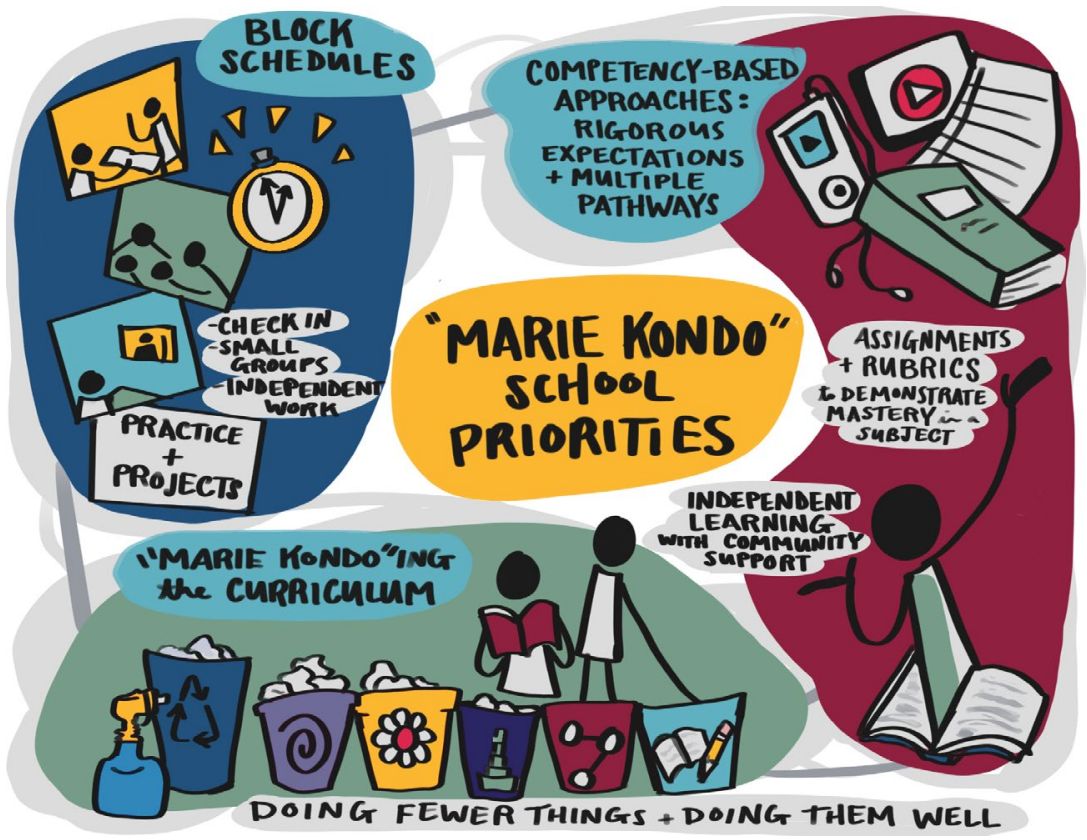
buoyant spirits and an optimism that they can do great work to serve students, especially our most marginalized, while at the same time facing the daunting realities ahead. To respond to this tension between serious obstacles and the vital importance of success, the most promising path forward is to focus: to do fewer things and do them all well.

Perhaps the most stark examples of focusing school priorities in recent decades connects with standards-based reform and test-based accountability. Especially when working with "bubble kids" -- students who score right on the cusp of "proficient" on standardized tests --schools made dramatic cuts to the curriculum by reducing time and attention to science, social studies, civics, the arts, physical education, recess, extracurricular activities, social-emotional curriculum, and many of the the things that teachers and students love about school. These cuts make room for schools to focus on test preparation for English Language Arts tests (really just reading tests) and Mathematics tests (really just computation tests). This path will be familiar and readily available to schools, but the costs of such an approach to teacher and student morale and to a comprehensive education are now well known to anyone who has taught during the era of standards-based school reform.

The alternative is not to retreat into test prep, but to make strategic curriculum reductions across the content areas so that students study a rich array of topics, but they study fewer of them and more deeply. Schools need to look across a range of routines and practices, find those that take up time and aren't working well, and reallocate their efforts to a smaller number of well-crafted lessons, programs, and experiences that nurture relationships, support youth resilience, and build knowledge and skills that prepare students for the challenges of school and beyond.

\section{Next Steps: Prototyping and Storyboards}

One of the best decisions we made was to Marie Kondo the curriculum. I'd heard of Marie Kondo--that Japanese cleaning expert who says that you should declutter your house by removing all items that don't spark joy--but l'd never heard her name used as a verb, and I'd never thought of applying it to the school curriculum.

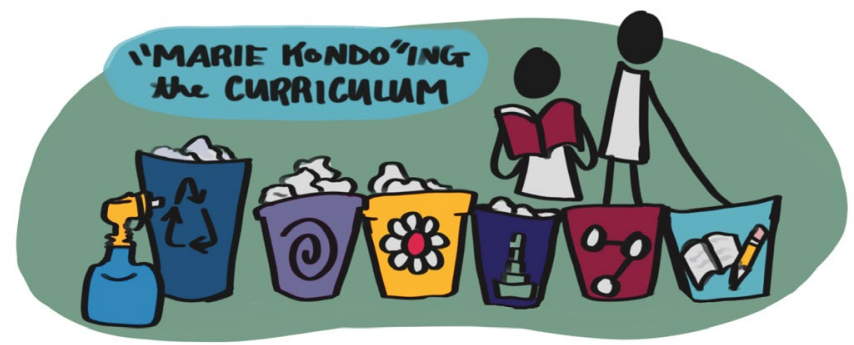


At first, we weren't going to do this. The first plan was to do double blocks of reading and math in order to catch up the students who were "behind." But we realized there were several problems. One, we didn't have enough school time to do that if we wanted to. Students had missed not just math and reading, but also science and history and Spanish, and thus everyone wanted extra time to "catch them up." But at the same time, we were operating with about half as much in-person time as before. Second, it was clear that no one wanted to use our limited in-person time this way. Students were looking for community after long periods of time away from their friends and their teachers. The last thing anyone wanted to do was rush through all of this material in a drill and kill sort of way.

Marie Kondo-ing the curriculum was a much better solution. We had teams of teachers look through the curriculum, subject by subject, and figure out what was really essential and what we could let go. We had them divide the curriculum into five buckets:

1. Topics that spiral: Lots of topics repeat over the course of years, like for example, how to write an argumentative essay. Students could move on to the next grade without doing these again.

2. Nice to haves: There are lots of these in the curriculum. Topics that some group of adults thought it would be nice if students knew, but aren't really essential. We let go of a lot of these.

3. Sequential topics: There are some topics, particularly in math and foreign language, where one topic really does build from another. Even with these, however, we were judicious -- making sure that we taught just what we needed to do the next -- rather than trying to do everything that we might have done the previous year.

4. Essential topics: Shakespeare. Dubois. Darwin. Keep.

5. Skills like reading and writing, that benefit from repeated practice: We kept these but rather than "drill and kill" we integrated them into the units we were developing for next year.

After doing this inventory, we felt much better. We had a responsible answer to the question of how to "catch up" kids. But we also had lots of space to work on fewer topics, which allowed for more depth and more inquiry. Especially since the students were home half the time, it was really important for us to build strong relationships and classroom communities, and embracing these integrated topics allowed us to do that.

\section{Further Reading:}

Jal Mehta and Shanna Peeples. Marie Kondo the Curriculum. Shanker Institute Blog. https://www.shankerinstitute.org/blog/marie-kondo-curriculum

\section{Competency-Based Approaches: Rigorous Expectations and Multiple Pathways}

Our principal had been talking about competency-based approaches and mastery learning for the last few years, and a few of the teachers went on trips to some competency-based schools in the area. A few of us incorporated some of the practices in our own classrooms-- clear expectations and rubrics, multiple chances for retakes and improvement, and grades more focused on final performances than progress along the way--but we didn't really make big changes as a school.

When we got together last summer and we realized what we were up against, we decided that we needed to make some big changes. With students home half the time, and with them needing to mostly stay in their seats at school, most of the learning that was going to happen was going to be very individual in nature. Some of our students kept up with everything last spring, and some basically fell off the map. Every year, our students were in different spaces, but this year, the differences were stark. We decided the best way to help everyone move forward was to

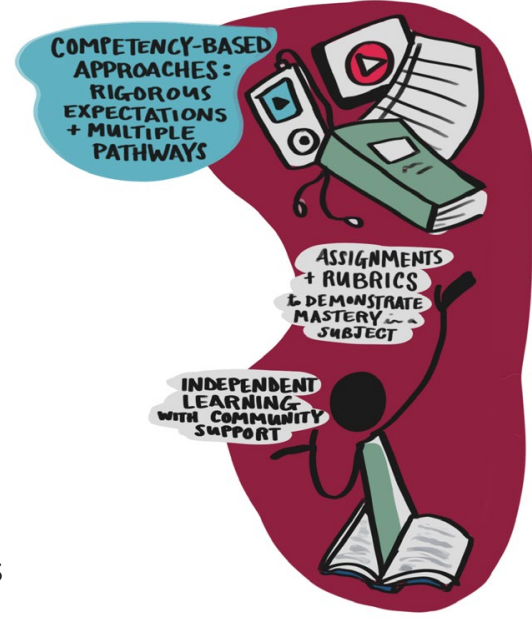
implement a mastery learning model for the whole year. 
For each unit, we developed a clear set of assignments and rubrics so students knew how they could demonstrate their mastery in a subject. Depending on the subject and topic, we tried to offer multiple ways of demonstrating mastery-- tests, essays, projects, and even oral examinations. Then, we compiled lots of different resources to help students make progress towards mastery-- textbooks, videos, online programs, and other things we could find. We still provide teacher instruction on almost every topic, but if students can learn things on their own, we support them.

One important rule was that everyone had to start with the new curriculum for this year. As much as possible, we didn't ask students who missed seventh grade spring to start back there. Rather, we started with eighth grade materials, and when students hit a roadblock that they needed something from last year, we provide some tutorials or resources. For some subjects like history and science, most classes are all new material so it doesn't matter that much, but the math teachers had more work to do some plugs and patches.

There have been some rough edges in the roll-out, but generally things are going well. We told the students that the big theme for the year was "Independent Learning with Community Support." Everyone does their best to keep themselves organized, and make progress against their learning goals and projects every day, and then when people get stuck, we really work together as a community to do peer tutoring or teacher tutorials or whatever people need to get unstuck. Like everything else, it works better for some kids than for others, but I'm glad that we decided to try some really big changes to accommodate a crazy year, rather than trying to keep doing regular school when regular school is impossible.

\section{Further Reading:}

Justin Reich. What is Competency-Based Education?

https://www.youtube.com/watch?v=RschZFj3vHI

\section{Block Schedules}

We implemented a block schedule this year, and it's really helping to simplify things for everyone. Every day starts with advisories, and whether we are home or in school, we check in with our advisor, talk about what's going on, and make a plan for a day. If we all have our stuff together, we just play a round of Jackbox trivia.

Then there is morning block, lunch and social break, afternoon block, and projects and practice. Each block is two hours long, and classes get two blocks a week. Different teachers have different routines for each block. A few AP teachers will do a whole synchronous class the whole time, but most don't. Usually teachers do a quick video or chat synchronous check-in, and then small groups of 4-6 meet with the teacher for 20-30 minutes, and everyone else works independently or in small groups. At the end of class, there is usually some kind

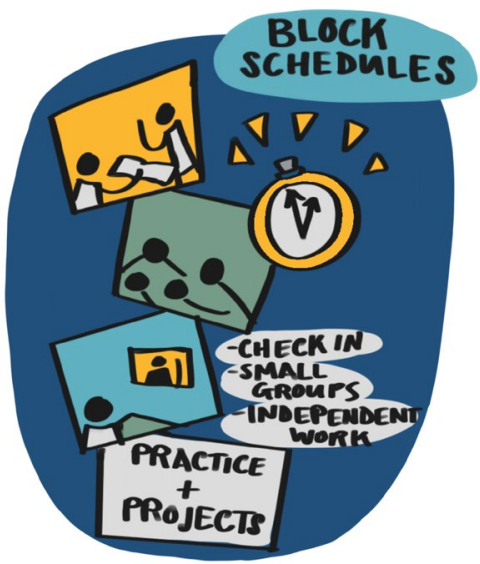
of debrief. I have one teacher who calls it the "Shipping Check," and he ends class by asking us all what work we finished or "shipped" during the period. Usually teachers let us pick what small groups we are in, so like if you are really confused you can ask to be in the small group in the beginning of the block to get help figuring out what to do. Or if you miss your small group because you were looking after a sibling or had to check in with another teacher, you can just switch to one of the other small groups.

We usually only use the whole blocks for special guests that come in, like for Career Days, or for big project presentations and stuff. 
At the end of the day we have a "practice and projects" block. Some days clubs meet during that time, but there are no classes and no teacher meetings, so if you need extra help you can find teachers to help you. If you are really falling behind in your work, than you have a kind of study hall check in during that period, where a teacher or a counselor or somebody makes sure you have a plan for what to work on and what to do, but if you are doing fine you can just use the time how you want.

During regular school, I like having lots of different classes and moving around and stuff, but during remote learning, it was really confusing to have to do work for 6 different classes every day. I have to do a little bit of math and Spanish practice everyday, but it's a lot easier just to do two big class blocks every day with plenty of time for us all to meet with the teacher without a big zoom meeting.

\section{Further Reading:}

Michael Rettig. The Effects of Block Scheduling. ASSA: The School Superintendents Association: https://www.aasa.org/schooladministratorarticle.aspx?id=14852 


\section{Building Time Will be "Gold"}

Under the current versions of the Centers for Disease Control and Prevention (CDC) guidelines for school re-openings, it would be nearly impossible in most places throughout the United States for all students to come back to school everyday. If the recommendations are to have groups of 12 , with no more than 10 students and 2 teachers with a class, then most schools simply do not have the staffing ratios in place to have everyone come back into the building all of the time.

Not all experts agree with this guidance. Some argue that the threat of transmissions among children is low enough that as long as adults practice social distancing, maskwearing, and other basic hygiene practices, both adults and students are likely to be

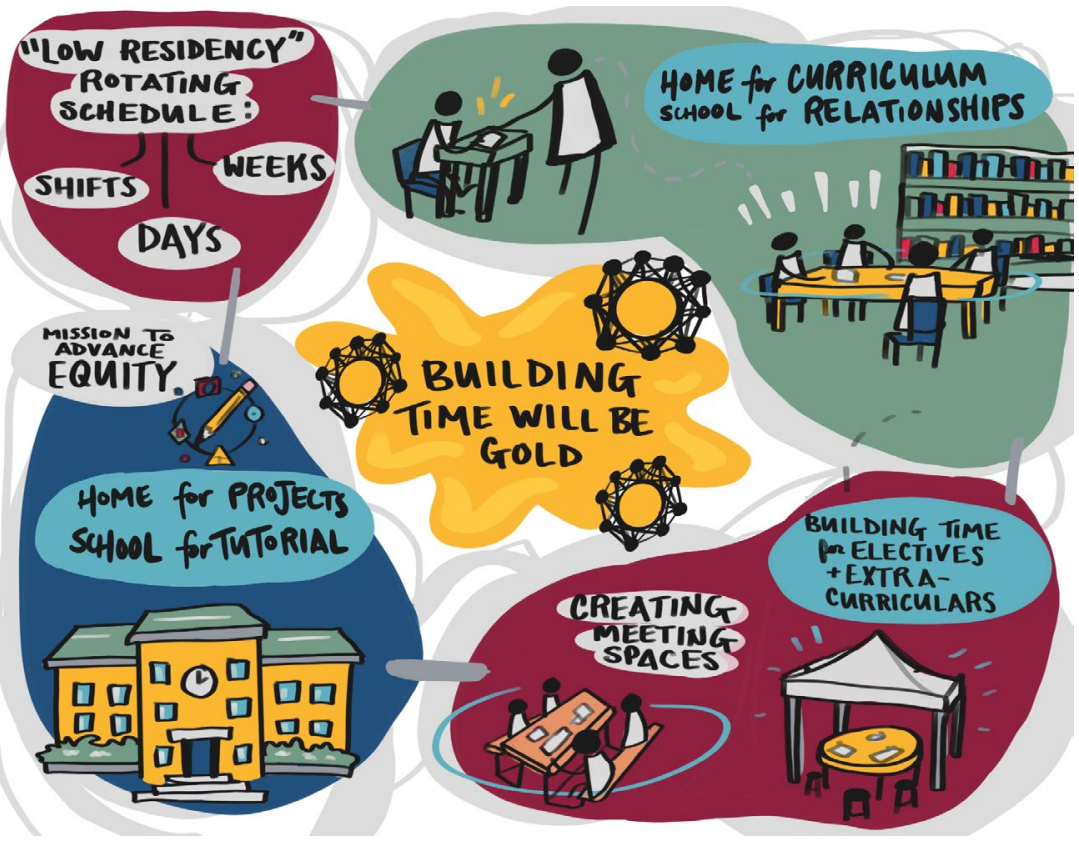
relatively safe. The risks to educational progress, mental health, and physical well-being of keeping students out of school may be greater than the risks to health from having them return to school. Others note that the teaching profession has many older adults in the "high-risk" category as susceptible to COVID-19, and teachers--like grocery store clerks and delivery workers--should not be expected to take mortal risks to go to work. These risks are also shaped by local factors--areas with active COVID spread and growth will find it harder to re-open, while some depopulated communities in rural America may have enough building space and teachers for most students to return to school.

One of the most important insights from school closures is the incredible importance of physical school buildings to the work of schools. Place matters, co-presence matters, physical structures matter. School buildings are among the most important resources we have to advance the equity mission of schools; being in the same place with the same resources is a powerful leveler. As an Arlington, MA, elementary school principal described it, "At the beginning of the year, we had 458 students in one shared space. Now we are teaching students in 458 different spaces." Next fall, in every place where building usage needs to be "low-residency"--where students need to rotate shifts, days, or weeks, or where some students stay home to make room for other students--building time will be the most precious resource that schools allot to students. As one district leader said in our design charrettes, "building time will be 'gold." How schools and districts choose to spend this golden resource will be among the most consequential decisions made in the coming weeks.

\section{Building time for Electives and Extracurriculars}

At the opening of school, our principal Mr. Jeffers told us that even though we couldn't come to school every day, he wanted to make sure that when we did come into school, it was for all of the things that we really love about school. He said, for every student, when we come into school, at least $50 \%$ of our time should be spent on electives and extracurricular activities.

Over the summer, the custodians went across the whole campus and made everything a meeting space. Like everything. The library is now a bunch of meeting spaces broken up by shelves,

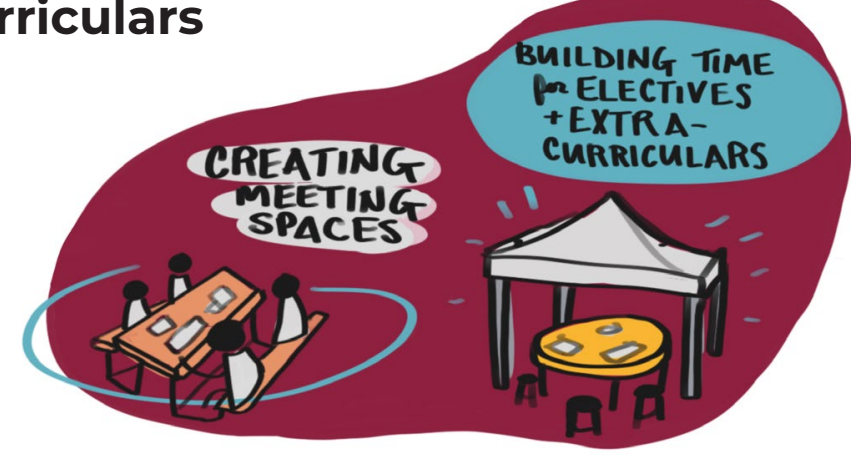


the gym and the cafeteria are meeting spaces with big plastic walls. There are tents all over the playing fields so that people can meet outside. There are crazy arrows all over the floors that make sure that everyone only walks one way down the hallway, so sometimes it can take a really long time to walk to somewhere that's the wrong way behind you, even if it's close.

All of the different clubs have meeting spaces, and teachers have meeting spaces for running different elective courses. The forensics class meets outside and there is a new murder case underneath the tent every week. The debate club, the esports club, the Spanish club, the yearbook all have meeting spaces. There are also a bunch of meeting spaces for tutoring and extra help.

Everyone comes into school two days a week, and works from home the other three days a week. If you don't get all your regular work done at home, then when you come to school you have to spend at least half your day in your homeroom finishing up your work and getting extra help from your homeroom teachers. But if you get all of your regular work finished, then you can just spend the day doing electives. Most of the clubs either don't have a faculty advisor or they have one that just comes in through Zoom. They are trying to only have the students move around the building, and to have the teachers limit their contact and moving since they are more at risk of getting coronavirus. Most of the clubs and even some electives have seniors who are in charge of them, so a lot of it is being run by the senior class.

I always try to get all my work done, and then I spend the morning outside doing forensics and the afternoon in the library doing esports.

\section{Home for Curriculum, School for Relationships}

So this year, the online learning is pretty similar to when schools closed last spring. We have projects every two to four weeks in our classes, and the projects are always online. When we do a project launch, there is a big shared doc at the beginning of the project where we get put into teams, discuss the framing questions, see some of the work that we'll do, and learn about the project presentations.

When we have to be home for remote learning days, we try to mostly do the background reading, and the reading responses, and the worksheets and other stuff like that. We watch the

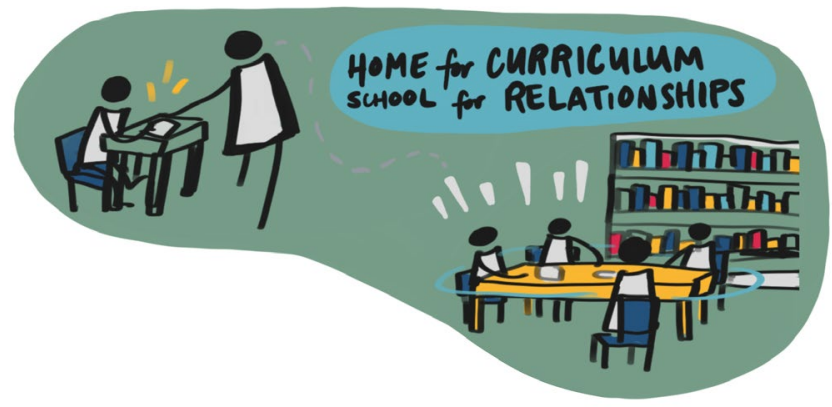
videos about stuff, and we have online small group meetings, and there are office hours, but I usually don't go. It was kind of chaotic and confusing when we started online learning last spring, but now everyone basically knows how to do it. So our online learning is mostly like regular school stuff, like the stuff I did before I went to a project based school.

So, when we go into school, we don't really do that many lectures, or worksheets, or stuff. We have advisory in the morning and we talk about the protests, and the recession, and the election and stuff like that. We start every Monday with "Meaning Mondays," where we talk about whatever is important to us or the things that are bothering us and stuff. We talk about all the stuff that's really hard to talk about on WebEx.

Then in classes, we have a mix of one-on-one check-ins with the teacher, or we work with our project partners. Last year, we usually did stuff in groups, but this year we mostly do pairs because it's easier with social distancing. We can still do some stuff in the science lab or in the makerspace, but it's less because only a few kids can do things at a time. Like the science teacher will help a couple of kids do a whole lab in a few hours, instead of having a whole class do it over a week's worth of class period.

So the online stuff is kind our routine, regular learning stuff. We do a lot of that at this school, so it's not that hard. When we come to school, we try to do the things that you can only do at school. 


\section{Home for Projects, School for Tutorial}

At my school, they are really strict about all of the coronavirus things. We get our temperatures checked every day, we have to wash our hands all the time, we use hand sanitizer in every class. And all of the desks are six feet apart, and they all face forward. When the desks are like that, you can't really talk to other students, except the ones that are near you, so the only things that can really happen at school are lecture, or teachers take their chairs and sit six feet in front of you and help you with stuff. My science teacher got this roller stool that he rolls around when he's not doing powerpoints.

Like in history class, when I'm in school my history teacher lectures us about stuff, and comes by our desks one by one and does individual feedback on our last debate, or we just work on our own on the debate prep and we can ask him questions and things. So school is

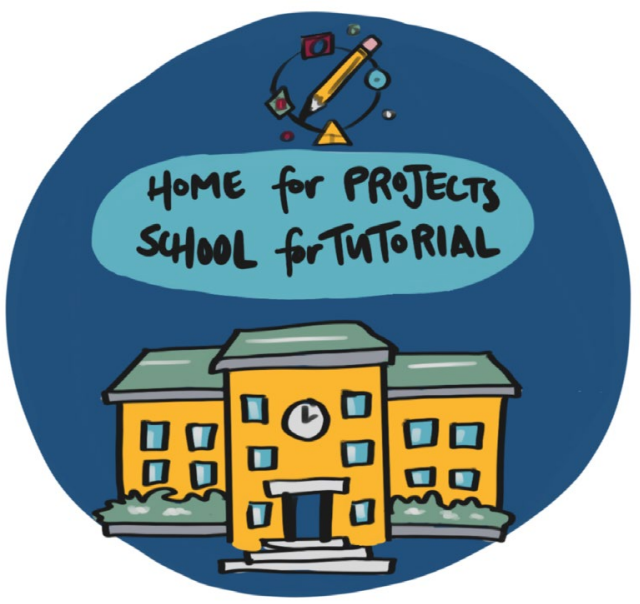
like where we learn all of the stuff, and then at home we figure out what to do with it.

So after we learn all of the stuff at school, we do most of our collaboration online. For the first couple of remote days, we'll work with our own team having practice debates. We'll talk about pro and con arguments, and give each other feedback, and we have to make slides and the teacher gives us feedback on them. Then, at the end of the unit we have a big debate online for a double online block. As a team we have to have prepared statements and rebuttals, but he cold calls us so we don't know who is going to have to talk. The debates are usually pretty hot, and sometimes people start yelling and stuff, but the teacher can just turn off all the mics when people get too crazy, and he tells us to cool it and we start again. It's usually pretty fun. The next day, we do a debrief where we all share what we thought were our favorite points and arguments. Next week, instead of doing a debate, we're going to make a podcast show.

I have a hard time concentrating online, so I'm glad that we do the kind of hard and boring stuff at school where there is a teacher to help me, and then once we know some stuff, we do all the fun, or at least the more fun things, online.

\section{Further Reading:}

New Mexico Council of State Science Supervisors. Supporting Students' Learning During COVID-19 School Closures with Distance Learning:

https://webnew.ped.state.nm.us/wp-content/uploads/2020/03/Educators-Distance-Learning-Toolkit Final.pdf 


\section{Nurture Home and Community Learning}

To formulate an oversimplified equation:

Student Learning $=$ School Learning + Home Learning

In 2020-2021, in most U.S. schools, school learning is going to decrease compared with typical years. Most schools cannot effectively run dual-track online/hybrid programs with students who have been functionally away from school for six months while dramatically increasing the resources devoted to health and custodial services, all during a recession where budgets and staffing levels have been decimated.

Since school learning will almost universally decrease in the coming year, the only way to maintain student learning is for home learning to increase. Parents and caregivers have already begun to bear this burden, but by all accounts, parents--especially mothers-

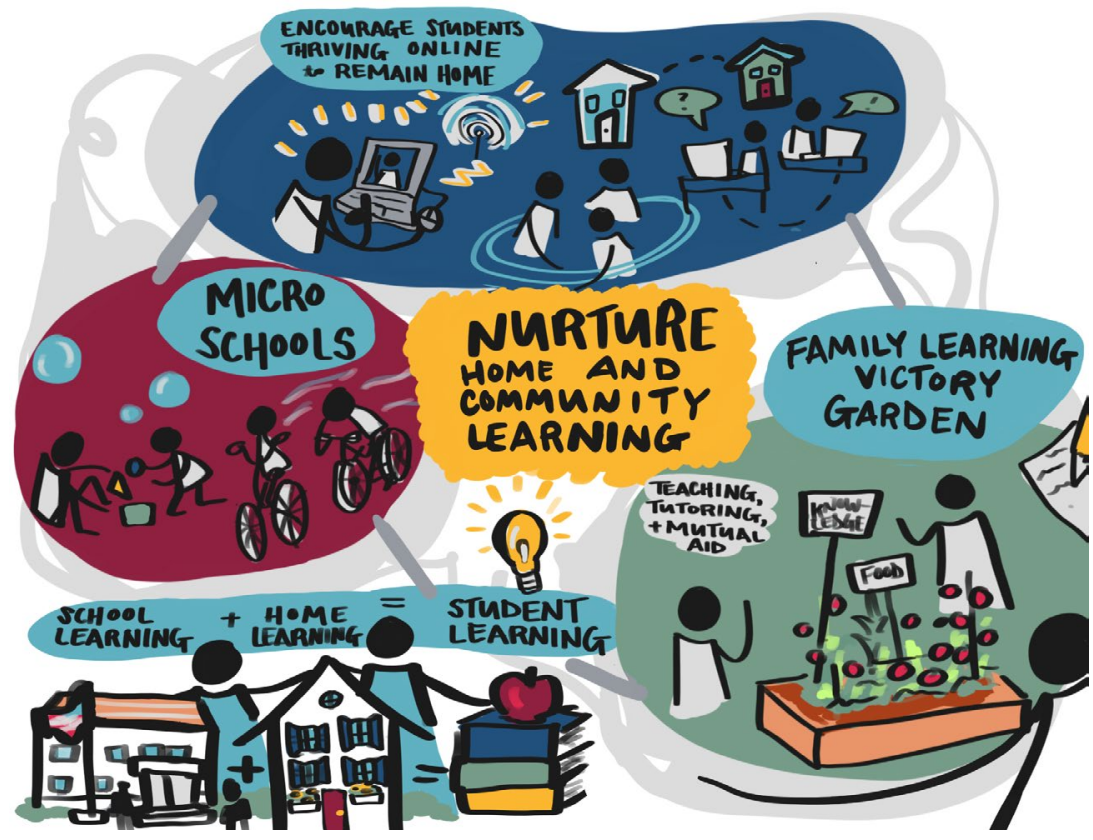
-have dramatically increased the amount of time they spend on supporting student learning.

This massive investment of time in our children must continue into next year. Wherever possible, parents, neighbors, family members, and caregivers need to plan to devote a substantial amount of time next year to providing supervision and learning support to students. Since many parents have full-time working responsibilities, schools, social service organizations, and communities need to place a special focus on rallying behind students who have less support for learning at home. In the absence of a top-down, massive federal stimulus package for schools, which does not appear to be forthcoming, the only plausible means of maintaining learning at anything like typical levels will require a massive, bottom-up, family and community commitment to supporting young people's learning next year.

\section{Family Learning Victory Garden}

Thursday is now officially my favorite day, because it's Vietnam War history day. My grandad is a huge Vietnam War history buff, and since I'm in US II this year, every Thursday he's teaching me my own mini-class on Vietnam, and if we finish that, we'll do the Iraq War too. We read articles and watch videos and stuff, and he tells me stories and shows me some of the things that he collected from his own deployment. It's awesome.

I'm doing a lot of these classes this year. My older sister, who is in college, tutors me a couple of times a week on math, and then my dad spends an hour with me every night to do homework help. He has this big book of Sudoku that he's working through, and we sit on the couch. He helps me make a plan for everything I need to do, then he does Sudoku and helps me if I have questions, or just makes sure that I stay

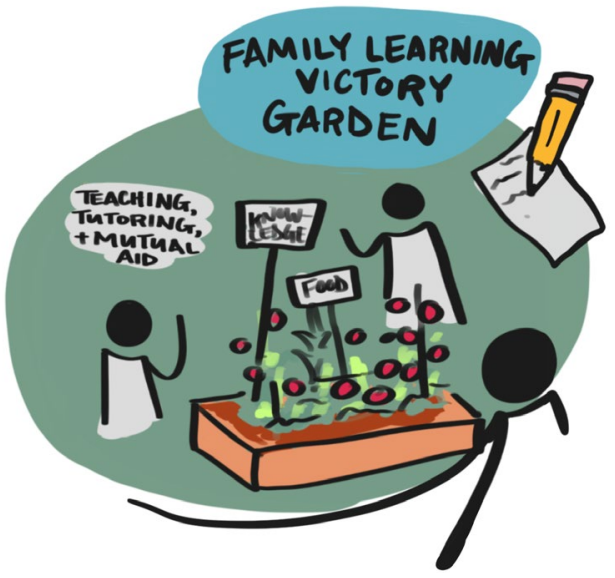
on track. He usually watches Netflix at night, but mom won't let him while he's supposed to be helping me. I like spending more time together. 
My mom started this mutual-aid-learning committee, and it is meeting tonight. It's kind of like the mutual-aid groups that made sure everyone had food and masks right when coronavirus hit, but instead it's for students in the neighborhood. They've been finding lots of families who can volunteer to help with stuff. Some families have offered to let their neighbors' kids come over at night to get their homework done, since the other parents work late. Some people in the neighborhood who are good at teaching or tutoring are offering classes or tutoring in their yards or in their parks or in the library.

\section{Microschools}

My parents had been pretty strict all summer with social distancing, but they finally let us form a bubble with three other families in our apartment complex! There are going to be 10 kids in all. Most of us go to the King Elementary School, but there are two kids in middle school and two babies. We still have to wear masks when we ride bikes and go to the playground, but when we visit each other's apartments, we don't have to wear masks. We can eat at each other's places, and play video games on the couch next to each other and stuff. But if one of us gets sick, we all have to go back to being at home by ourselves for two weeks.

We signed up with the school to be a microschool, and they are letting us all go to school for Monday/Tuesday, and then we stay

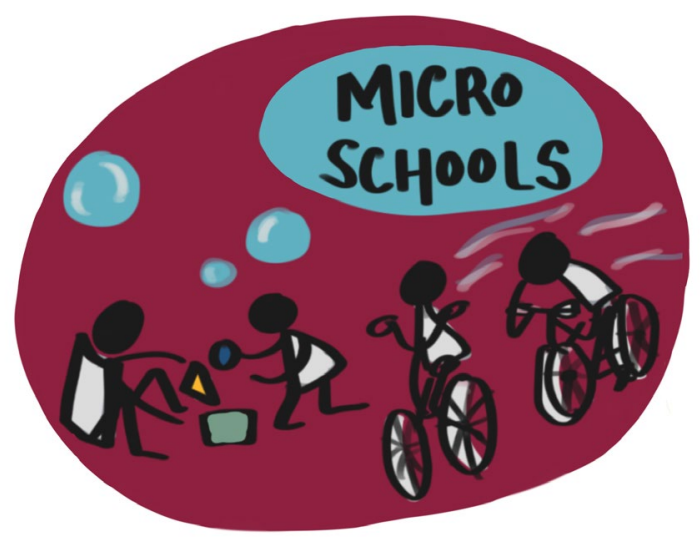
home Wednesday/Thursday/Friday. All of us kids who go to the King are going to rotate between apartments each day we're home. One parent will help us with remote school stuff and food and things, and then the other parents can go to work. We decided that the older kids will do online things in the morning, and then do other work or play in the afternoon, and the younger kids will do the opposite, so we have enough internet and computers for everybody. When we do go to school, we're going to be allowed to sit next to each other in class and to play with each other at recess.

So far, it's a lot better than this spring. The older kids help me with my work, and I help some of the younger kids, and there are more folks around to play with at home. Robert's mom is really good at math, so I like when we are at his apartment because she can help me. My parents said that even if the whole school has to close down because of coronavirus this winter, we can still keep being a microschool as long as we all stay healthy.

\section{Further Reading:}

Anya Kamenetz. Five Radical Schooling Ideas for an Uncertain Fall and Beyond. NPRed. https://www.npr.org/2020/06/17/878205853/5-radical-schooling-ideas-for-an-uncertain-fall-and-beyond

\section{Encourage Students Thriving Online to Remain Home}

Last spring my mom showed me this op-ed from a girl who really liked remote learning, and I was like, "Yup, that's me." At school, I was bored in class and I hated all the drama in the halls. When school was canceled and we all had to go home, I realized that it wasn't school work that was stressing me out so much, it was school. Even though we didn't have grades or anything last spring, I still did all the work because I wanted to be ready for junior year, this year.

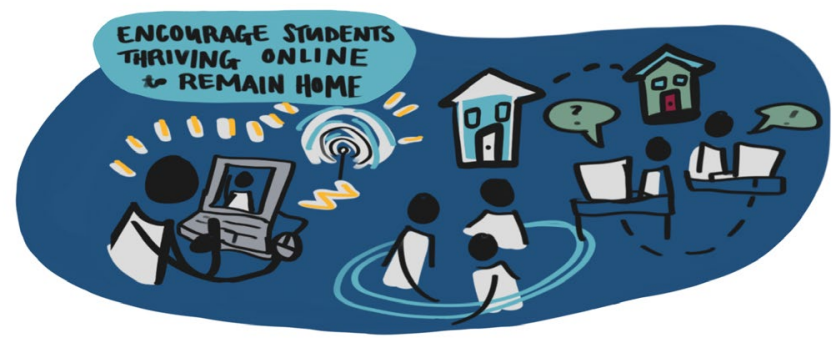


This summer, the school sent notes home to every parent asking them if their child wanted to participate in a full year of remote learning, and I said "Sign me up!" Since our overcrowded building can only fit about one third of the students at any time, kids have to rotate different days being at school. So they asked all of the families to consider whether they can have their kids learn from home. There was a little printout with my note that said that all of my teachers thought that I would do well online. And my parents think I'm pretty responsible, so they are letting me stay home while they are at work. So far, it's going pretty good.

All of my classes now are taught by the older teachers, since those were the ones who really didn't want to go back to school. Most of them are actually pretty good, and I think they might be doing better than some of the other teachers, because they only have to do remote learning full time; they don't have to try to do classroom teaching and online teaching. About $20 \%$ of kids in my high school agreed to stay home, and they only let good students do it; if you had trouble with grades and attendance and stuff you had to go back to school. So all of my classes are kind of like honors classes now. But I think it's helping some of the other students too, because when kids do go in, all of their class sizes are a lot smaller. 


\section{Iterative Organizational Learning}

Organizational learning--where individual team members and organizational processes improve as organizations carry out their day-to-day work--has long been a goal for schools. However, the ways that most schools are still organized--egg crate classrooms with single teachers working in isolation and the urgent nature of the job--has traditionally inhibited efforts to create ongoing organizational learning. In a pandemic, with everyone teaching in potentially new situations (hybrid between in-person and at-home learning), creating the time and space for these kinds of collaborations is critical. Since inevitably some teachers, teacher teams, and schools will figure out things that work faster than others, if we build in the structural space for this learning, we can get better much

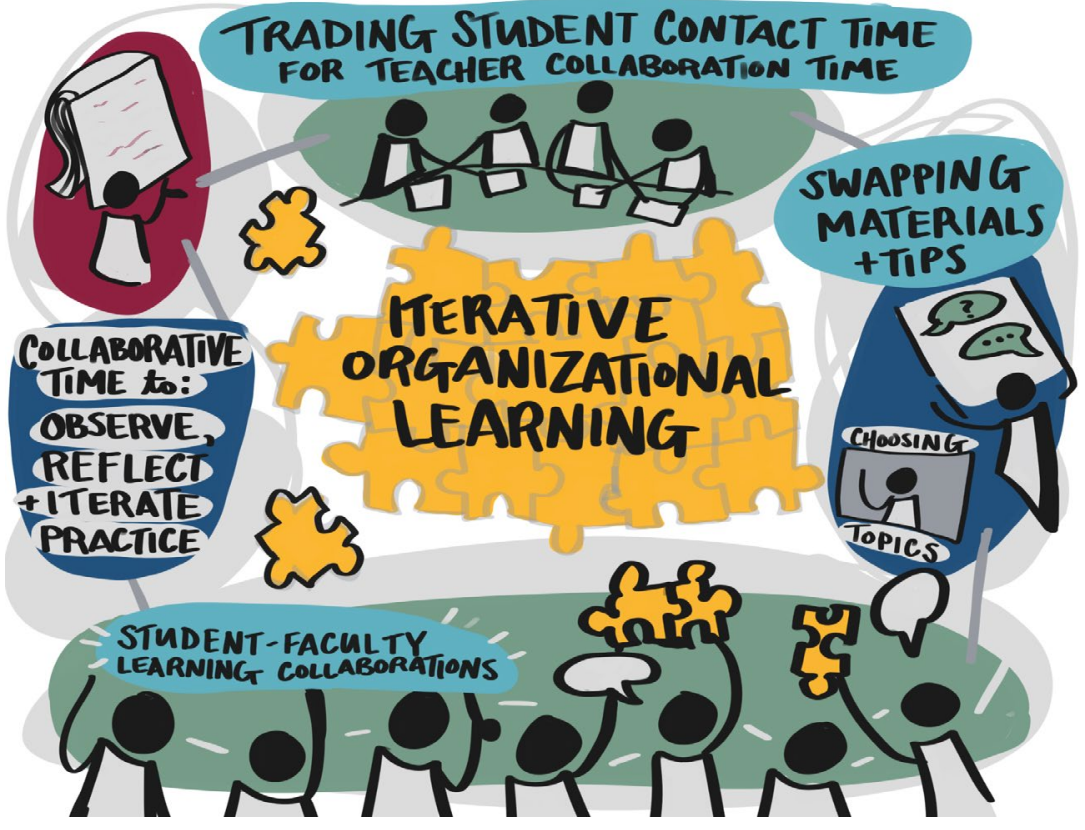
faster. Conversely, if successful innovations remain localized, we have very little chance of adapting quickly enough at scale to create success. Key aspects of organizational learning include: (1) regular collaborative time to observe, reflect on, and iterate practice,(2) ways to network laterally across classrooms, teams, and schools to share emerging practice and learn from each other and (3) organizational responses that change the infrastructure to turn ongoing learning and emerging innovations into regular practice.

\section{Trading Student Contact Time for Teacher Collaboration Time}

Last year was just overwhelming. We had to move everything online, and we had very little time to do it. I teach middle school science, and I had to figure out how to do labs remotely, and a hundred other things, and I didn't really have any time or support to do it.

This year is different. The superintendent began the year by saying that he had been reading about how they do things in those

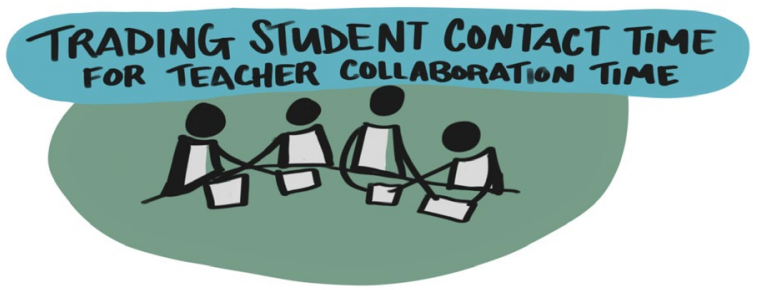
countries that lead the PISA rankings, and he noticed that there were many fewer contact hours with students, and more time to plan with one another. On that basis, he has declared that the first hour of each day is for teachers to plan together. Students are used to getting up later now anyway, and with limited sports, it's not really a problem to end a little later.

For me, that time is a godsend. On Mondays and Wednesdays we do Zoom calls across the district. Unlike traditional professional development, we get to name the topics and then whomever is interested in those topics gets to join. We started these last year when we were all working from home, and I found myself really on the same page with a couple of science teachers from Jackson Middle, who really seem to see the world the way I do. I tell them what I'm planning and get advice, we swap materials, and exchange tips for how to balance between what students can do online and what they can do in person.

On Tuesdays and Thursdays, I meet with the grade level team, and we talk about the kids. Who is doing well, who is struggling, what we are seeing from our various perspectives. At the beginning it was a little cumbersome, but 
we've developed a good rhythm, and, now that most of our students are on track, we have a little more room to devote to devising plans for those who are most struggling.

On Friday, we talk about whole school issues. We get to nominate topics over the course of the week, and then we devote our whole group time to whatever seems most salient. We were getting a lot of complaints initially that students had too many small assignments to keep track of, so we developed a system where different subjects rotated who got to use the home learning time. We are hoping by the spring to have developed some crossdisciplinary projects as well.

I don't know what we would do without this time. There has been so much to figure out, and it is so much better to be doing some of that figuring out together. We didn't have it all exactly right at the beginning, but over the course of the year we were able to gradually iterate until we found some things that worked.

\section{Further Reading:}

Michael Petrilli. Half-Time High School may be just what students need. Fordham Institute. https://fordhaminstitute.org/national/commentary/half-time-high-school-may-be-just-what-students-need

\section{Student-Faculty Learning Collaborations}

School, as long as I've known it, was a place where we came and they told us what to do. But this year, there seems to be a new attitude: we will figure it out together.

A little background: We are home every other day because of social distancing requirements. So my physics teacher,

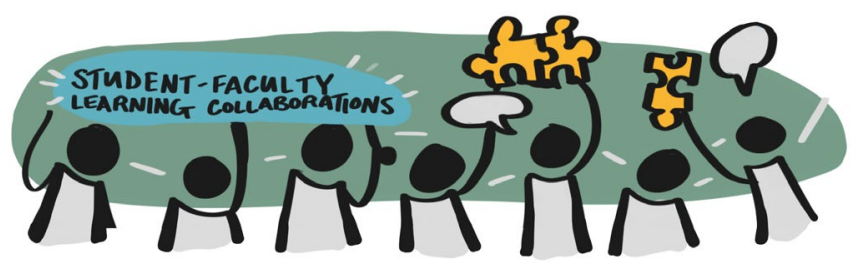

Mrs. Kimble, told us that we were going to figure out how to best use that time together.

At the beginning of the year, she thought that she could teach us the material on one day, and then have us work on it the next day, kind of like homework. But because she was trying to really teach two days of material in one, it wasn't working that well. We also found it hard to do large chunks of work at home on the off days without her help.

We've moved to a different model. She has flipped the lectures so that we all watch them at home. Then on the days where we are physically there, we do more interactive activities, like discussions and she also answers our questions. We also have some silent work time during our 90 minute block. On the days where we are home, Mrs. Kimble is available to answer our questions while the students in class are doing silent work time.

We've also developed a peer tutoring method. There are some kids in the class who really seem to get it more easily, and they are peer tutors. When we are in class, sometimes they circulate and offer help, and when we are home, they are available over chat to answer questions.

If we ever get a vaccine and go back to normal school, I hope that they will continue to be interested in learning from us. It's so much easier to find something that works if we are involved in the process! 


\section{Conclusion}

School communities, families, and educators face enormous challenges in the months ahead as they design and participate in schooling systems that educate students while keeping families and staff safe. There is no single answer to these dilemmas, and schooling will look different in rural hamlets, urban centers, and the wide swaths of suburbia. We hope that the stories that we have told above stretch your imagination of what's possible, invite you to consider which of these stories are desirable and which are dystopic, and to begin developing your own narratives and storyboards for schooling in 2020. 


\section{Charrette Participants}

We gratefully acknowledge the ideas, feedback, and contributions from the following participants in our online design charrettes:

Neema Avashia

Heather Wolpert-Gawron

Lis Layhee

Alisa Berger

Jessica Rose

Devon LaRosa

Jason Glass

Amelia Peterson

Shawn Rubin

Shanna Peebles

Tyler Thigpen

Kristen Ferris

Kevin Bryant

Sumbul Siddiqui

Kenneth Salim

Thomas McDermott

Rod Allen

Alfred Solis

Noah Holmes
McCormack Middle School, Dorchester MA

San Gabriel Unified School District

Saranac Elementary School

Deeper Learning Dozen

Lincoln Public School

Madison Metro School

Jeffco Public Schools

Harvard Graduate School of Education, London

School of Economics

Highlander Institute

Harvard Graduate School of Education (Prior: National Teacher of the Year)

The Forest School \& The Institute of Self Directed Learning

Lincoln Public School parent and K-12 consultant on school district resource strategy

Harvard Graduate School of Education (Prior:

Principal, NYC Public Schools)

City of Cambridge

Cambridge Public Schools

Jeffco Public Schools

Deeper Learning Dozen

$X Q$

The Forest School 
Ronni Moore

Purdue Polytechnic High School North

Chris Lehmann

Science Leadership Academy Schools

Sharon Hobbs

Lincoln Public Schools, Lincoln, MA

Dan Coleman, Ph.D

Big Sky Blue Design

Paul Leather

Center for Innovation in Education

Kevin Godden

Abbotsford School District

Daniel Wise

Prospect Hill Academy Charter School

Lin Johnson III

Harvard Graduate School of Education (Prior: Shelby County Schools)

Linda Eno

NJ DOE

Tamir Harper

UrbEd

Sarah Kyriazis

Worcester Public Schools 